УДК 316.356.2:3:4:75

\section{Людмила Ліпіч}

\section{Сім'я та сімейні иінності 8 умовах трансформачіӥ традиційних соціальних інститутів}

Анотація: Стаття присвячена трансформації інституту сім'ї та сімейних цінностей в умовах глобалізації неоліберального типу. Метою статті $є$ опис процесу реінституціалізації традиційної сім'ї в нетрадиційну та відповідних змін у сімейних цінностях.

Метод дослідження - порівняльний аналіз традиційного інституту сім'ї з нетрадиційним.

Уточнюється, що розуміння соціальної необхідності сім'ї як соціальної групи задля задоволення потреб суспільства у фізичному та духовному відтворенні населення є не соціологічною, а демографічною характеристикою. Обгрунтовується потреба відрізняти соціальну функцію сім'ї від демографічної. Перша полягає у відтворенні соціальної структури та соціалізації, а друга - у відтворенні населення. В статті порівняно інформацію Євростата та World Values Survey - 2017 із результатами всеукраїнських соціологічних досліджень, що проводилися з липня по серпень 2017 року Центром незалежних соціологічних досліджень «Омега», на замовлення Міністерства молоді та спорту України, «Молодь України 2017» i «Українське покоління Z. Цінності та орієнтири» - компанією GfK Ukraine, на замовлення Центру «Нова Європа». В результаті порівняння зроблено наступні висновки: трансформація інституту сім'ї в українському суспільстві повільно відбиває загальноєвропейські тенденції. Втім, якщо для України це можна розглядати як тенден- цію, то для європейських країн - як закономірний процес, під час якого вже відбулися істотні ментальні зміни. Відзначається, що трансформацію сімейних цінностей необхідно розглядати в контексті відповідних законодавчих ініціатив, які пов'язані з процесом реінституціалізації сімейних відносин. Підкреслюється, що традиційний інститут сім'ї грунтується на природно-історичних законах, у відповідності з якими вибудовується сімейна політика.

На основі аналізу причин трансформації традиційного інституту сім'ї в нетрадиційний, описаних у відомому бестселері американського соціолога і футуролога Е. Тоффлера «Шок майбутнього» («Future shock»,1970 р.) робиться спроба обгрунтування ролі державної політики в процесах деінституціалізації і реінституціалізаціі сім'ї. Доводиться, що головною причиною появи нетрадиційного інституту є зростання витрат держави на підтримку традиційної сім'ї. Дана обставина інтерпретується як збитки, які мають бути скорочені.

Одружена людина має підтримувати сім'ю, а неодружена - лише саму себе. Коли дозволити їй перебувати у позашлюбних, безшлюбних та невпорядкованих статевих відносинах, включаючи одностатеві, інститут сім'ї втрачає сенс, а економічні збитки через ії підтримку значно зменшуються. Соціальна енергія індивідів починає витрачатися не на розв'язання соціальних проблем, що виникають на стику міжгрупових відносин, а на пошук статевого партнера та захист права на вільний пошук. Тут починає діяти фрейдівська сублімація як захисний механізм зняття внутрішньої енергії, що породжується в опорі до соціальної несправедливості існуючого соціального устрою, але перенаправляється на досягнення права свободи у виборі статевого партнера. Отже, сублімація тут перетворюється зі статевої на сексуально-право-політичну. 
Визначено, що формування емансипативної системи цінностей в сучасному українському суспільстві відбувається під впливом ряду факторів глобалізаційного, державно-політичного, соціокультурного характеру. Особливу увагу автор звертає на те, що українська молодь, за даними всеукраїнських соціологічних досліджень, віддає перевагу соціальнокультурній значущості сім'ї і традищійним сімейним цінностям.

Результати дослідження можуть бути використані в курсах соціологічних дисциплін і розгортанні нових напрямів соціологічних досліджень.

Прогнозні припущення щодо розвитку об'єкта дослідження - пошук оптимальних шляхів збереження традиційних сімейних цінностей та інституту сім'ї в сучасному суспільстві.

Ключові слова: сім'я; сімейні цінності; традиційний соціальний інститут; нетрадиційний соціальний інститут.

\section{Liudmyla Lipich}

\section{Family and family values in the conditions of transformation of traditional social institutes}

Summary: The article is devoted to the transformation of the institute of family and family values under the conditions of globalization of the neoliberal type. The purpose of the article is to describe the process of reinstitualisation of a traditional family into a nontraditional one and the relevant changes of family values.

It is pointed out, that understanding the social importance of the family as a social group, that meets the needs of society in the physical and spiritual reproduction of the population is not a sociological, but a demographic characteristic. The necessity to distinguish the social function of the family from the demographic is substantiated. The first is to recreate the social structure and socialization, and the second - in the reproduction of the population. The article compares the information of Eurostat and World Values Survey 2017 with the results of all-Ukrainian sociological research conducted from July to August 2017 by the Center for Independent Sociological Research «Omega», commissioned by the Ministry of Youth and Sport of Ukraine, "Youth of Ukraine - 2017» and «Ukrainian Generation Z. Values and Landmarks» -by GfK Ukraine, commissioned by the New Europe Center. As a result of the comparison, the following conclusions were made: the transformation of the family institution in Ukrainian society slowly reflects pan-European tendencies. But if for Ukraine this can be considered as a trend, then for European countries - as a natural process, during which there were significant mental changes. It is noted that the transformation of family values should be considered in the context of relevant legislative initiatives that are associated with the process of re-institutionalization of family relations. It is emphasized that the traditional institute of the family is based on naturalhistorical laws, in accordance with which family policy is built up.

On the basis of an analysis of the reasons for the transformation of the traditional family institution into untraditional one, described in the well-known bestseller of the American sociologist and futurist E. Toffler, "The shock of the future" (Future shock, 1970), an attempt was made to justify the role of state policy in the process of deinstitutionalisation and reinstitutionalization of the family. It turns out that the main reason for the emergence of a non-traditional institute is the increase in state spending in support of the traditional family. This circumstance is interpreted as a 
loss to be reduced. A married man has to support a family, not a married one, only himself. If somebody allows to stay in extramarriage, crippling and disorderly sexual relationships, including the same-sex, the family institution loses its meaning, and the economic damage should be greatly reduced. The social energy of individuals begins to be spent not on the solving of social problems arised at the junction of intergroup relations, but in searching of a sexual partner and the protection of the right of free searching. Freudian sublimation begins to act here as a protective mechanism for the removal of internal energy, which is generated in support of the social injustice of the existing social system, but redirects to the achievement of the right to freedom in choosing a sexual partner.

Consequently, sublimation is transformed from sexual to sexual-legal-political type.

It is determined that the formation of the emancipative system of values in the modern Ukrainian society takes place under the influence of a number of factors of globalization, state-political, socio-cultural character. Particular attention is paid to the fact that the Ukrainian youth, according to all-Ukrainian sociological research, prefers the socio-cultural significance of the family and traditional family values.

The results of the study can be implemented in courses of sociological disciplines and the deployment of new areas of sociological research.

Foreseeable assumptions about the development of the research object are finding the best ways to preserve traditional family values and the family's institutes in the modern society.

Key words: family; family values; tradishional social institute; nontradishional social institute.
Постановка проблеми. Трансформація соціальних структур і відносин, зокрема сімейно-шлюбних, що відбувається під впливом глобалізації неоліберального типу, визначається переоцінкою цінностей інституційного порядку західного та пострадянського суспільств. Характер змін в традиційних соціальних інститутах, зокрема, сімейному, корелює, насамперед, 3 проблемами трансформації базових цінностей, культурних символів і зразків, диверсифікацією нетрадищійних цінностей і нетрадиційних форм сім'ї, шлюбу та сімейних відносин. Зміни у соціальних практиках все частіше пов' язані з розмитістю або нівелюванням національних традицій, традиційної системи сімейних цінностей тощо. Прикладами такого роду змін стають показники девальвації таких цінностей як сім'я, шлюб, батьківство, сім'я 3 дітьми, зв' язки між поколіннями в одній сім'ї тощо. Дані обставини актуалізують потребу у вивченні процесу трансформації сім'ї як одного із соціальних інститутів та трансформації сімейних цінностей.

Аналіз останніх досліджень і публікацій визначається багатоаспектністю і особливостями, які можуть бути представлені наступним чином:

Перша особливість полягає в тому, що основна увага науковців зосереджена на вивченні змін, що відбуваються в українському суспільстві, на соціальних процесах, що визначають ці зміни в соціальних структурах і соціальних відносинах. До них відносяться роботи методологічного та загальнотеоретичного характеру О. I. Вишняка, Є.І. Головахи, О.Д. Куценко, М. О. Макеєва, І. О. Мартинюка, М. А. Парашевіна, М. О. Шульги та інших.

Більшість авторів відзначає, що «у вітчизняній соціології вже $є$ певні теоретикометодологічні напрацювання щодо харак- 
теристик успадкованої структури інститутів і такої, що склалася в Україні під час запланованих та стихійних трансформацій і деформацій попереднього суспільного порядку» [Стан сингулярності 2017: 13].

Друга - дослідження аксіологічної парадигми українського суспільства в контексті трансформаційних процесів, подані в монографіях Л. О. Ази, В. П. Андрущенко, О. Г. Злобіної, В.М. Геєць, І. Е. Бекешкіної, М. П. Лукашевича, А. О. Ручки, С. I.Оксамитної, С. М.Цимбал та інших.

Третя - міждисциплінарні дослідження, в яких вивчаються найрізноманітніші аспекти: чинники, що впливають на форми сімейних відносин; структуру і рольову взаємодію в сім'ї; подружні ролі; сімейні відносини молодого подружжя; ставлення молоді до сімейного життя та батьківства; вплив трудової міграції на сім'ю, сімейні відносини та цінності тощо, тобто все те, що пов' язано 3 повсякденними сімейними практиками. Серед дослідників соціологи Л. Бучинська, М. Боришевський, С. Войтович, I. Дьоміна, В. Зацепін, О.Ковтун та ін., психологи та педагоги - В. Андрієнко, І.Андрєєва, О. Бондарчук, Н. Будяк, А. Галичанська, Я. Гілінський, Н. Гордієнко, Т. Гурко, Т. Кравченко, В. Левицький та інші.

Четверта - це дослідження системи цінностей молоді в роботах В. Бакірова, Т. Бондар, В. Баранівського, М. Головатого, Н. Костенко, О. Мусієздова, Л. Сокурянської, О.Яременко тощо.

П'ята особливість відзначається найбільш активними та системними дослідженнями гендерної проблематики: вивчення історії гендеру, узагальнення досвіду гендерної політики західних країн, гендерний аналіз повсякденності і сімейних практик в українському соціумі, гендерна соціалізація, формування вітчизняної гендерної політики. В цілому гендерна проблематика $є$ однією 3 найбільш популярних і поширених міждисциплінарних досліджень, що безпосередньо пов'язана 3 сім'єю та її цінностями.

В цій царині працюють Л.Амджадін О. Балакірєва, Н. Дмитрук, О. Іващенко, Н. Лавріненко, Т. Медіна, С. Оксамитна та інші.

Аналіз соціологічної літератури надав змогу зробити висновок, що проблема сім'ї та сімейних цінностей в умовах трансформації традиційних соціальних інститутів знаходиться в процесі становлення комплексних досліджень, що актуалізує потребує подальшого наукового напрацювання.

Мета роботи - опис процесу реінституціоналізації традиційної сім'ї на нетрадиційну та відповідних змін у сімейних цінностях.

Реалізація поставленої мети передбачає розв' язання наступних завдань:

- уточнити поняття: сім'я, традиційний соціальний інститут, нетрадиційний соціальний інститут, цінності, сімейні цінності;

- порівняти трансформаційні процеси в інститутах західної та української сім'ї;

- виявити взаємозв'язок системи сімейних цінностей $з$ політичними реаліями сьогодення;

- проаналізувати дані всеукраїнських соціологічних досліджень щодо сприйняття та відтворення/відхилення молоддю сімейних цінностей та інституту сім'ї.

Наукова новизна полягає в наступному:

1. Автором порушено питання щодо існуючої суперечності в поглядах на сім'ю в соціологічній літературі: 3 одного боку, спостерігається неправомірна редукція соціальних функцій сім'ї до демографічних (зокрема, до репродуктивної функції), а 3 другого, - замовчування того факту, що 
так звана нетрадиційна сім'я взагалі втрачає демографічні функції й, у першу чергу, репродуктивну. Так, задоволення потреб суспільства у фізичному та духовному відтворенні населення $\epsilon$ не соціальною, а демографічною функцією. Головна ж соціальна функція полягає у відтворенні соціальної структури суспільства та соціалізації.

2. Порівняно процеси трансформації, що відбуваються в традиційних інститутах сім'ї в західному і українському суспільствах. Ці процеси вперше оцінюються як процеси, яким притаманні загальні тенденції. Стверджується положення про те, що гендерна рівність не $є$ питанням про соціальну рівність між жінками та чоловіками, а лише питанням про право вибору (соціальної) статі, тобто про гендери.

3. Виявлено взаємозв'язок сім'ї та системи сімейних цінностей з політикою держави. Проаналізовано причини трансформації традиційного інституту сім'ї в нетрадиційний за книгою Е.Тоффлера «Шок майбутнього» («Futureshock»,1970р.)

4. Введено інформацію Євростата та World Values Survey - 2017 і результати всеукраїнських соціологічних досліджень: «Молодь України - 2017» і «Українське покоління Z. Цінності та орієнтири». Вперше порівняно результати всеукраїнських соціологічних досліджень за 2017 р. 3 інформацією Свростату та World Values Survey в аспекті ставлення до традиційного і нетрадиційного інститутів, традиційних і нетрадиційних сімейних цінностей. Виявлено, що на відміну від західного суспільства, в якому реінституціалізація нетрадиційного інституту сім'ї та нетрадиційних сімейних цінностей набула закономірного процесу і відзначається змінами в суспільній свідомості, в українському суспільстві, деінституціалізація традиційного інституту сім'ї і реінституціалізація нетрадиційного інституту сім'ї має подвійний характер: повільно відбиває загальноєвропейські тенденції, які не знаходять широкої підримки в суспільній думці, зокрема молоді; вищі диспозиції в системі цінностей української молоді посідають традиційні сімейні цінності і традиційний інститут сім'ї як цінність.

Виклад основного матеріалу. В інституційній структурі суспільства одним із найдавніших їі інститутів є сім'я. Водночас сім'я $\epsilon$ соціальною групою, що має історично означену організацію, члени якої пов'язані шлюбними або родинними стосунками, спільністю побуту та взаємною моральною відповідальністю, соціальна необхідність в якій обумовлена потребою суспільства у фізичному та духовному відтворенні населення [Соціологія 2010: 224]. Однак, таке визначення сім'ї є скоріше демографічним, аніж соціологічним, і тому потребує уточнення. Крім того, в ньому поєднано групові та інституціональні ознаки сім'ї.

Сім'я як соціальний інститут складається на основі статевих відносин з приводу продовження роду, а з виникненням держави формується ще й інститут шлюбу та шлюбних відносин.

Саме держава як соціальний інститут перебрала на себе одну з функцій сім'ї по відтворенню населення, але не як простої множини ऑï членів, а чітко вибудованої соціальної ієрархії та відповідної соціалізації нових ії членів.

Отже, розмови про те, що сім'я виконує функції 3 відтворення населення, господарсько-економічну, виховну, рекреаційну та соціального контролю, $є$ неповними, бо усі вони тепер пов'язані ще й з функцією відтворення соціальних нерівностей, тобто наявної соціально-групової структури суспільства.

Можливі відхилення у виконанні даної функції, що мають місце при переході з одного класу до іншого, а той при декласу- 
ванні, описуються теорією соціальної мобільності, основу якої заклав російсько-мериканський соціолог П. Сорокін [Сорокін 1992: 302-373], не впливають на ії стабільність.

Загальновідомо, що саме інститут сім'ї забезпепечує відносну стабільність сімейних зв'язків, родинних відносин та форм діяльності в межах досить суворої внутрішньої та зовнішньої соціальної організації. Таке відбувається на основі системи наявних правових, морально-етичних норм, цінностей та ідеалів, зразків діяльності та поведінки, які мають нормативний характер і врегульовують сімейно-родинні відносини, що і $є$ предметом державної сімейної політики.

Так, в «Сімейному Кодексі України» наголошується, що сім'я $є$ первинним та основним осередком суспільства. Сім'я створюється на підставі шлюбу, кровного споріднення, усиновлення, а також на інших підставах, не заборонених законом i таких, що не суперечать моральним засадам суспільства [Сімейний кодекс 2002: 3]. Регулювання сімейних відносин здійснюється Кодексом з метою: зміцнення сім'ї як соціального інституту і як союзу конкретних осіб; утвердження почуття обов'язку перед батьками, дітьми та іншими членами сім'ї; побудови сімейних відносин на паритетних засадах, на почуттях взаємної любові та поваги, взаємодопомоги і підтримки; забезпечення кожної дитини сімейним вихованням, можливістю духовного та фізичного розвитку [Сімейний кодекс 2002: 22-23]. Таким чином, статті Кодексу свідчать про те, що на законодавчому рівні зусилля української держави щодо сім'ї спрямовані на укріплення традиційних сімейних цінностей, що і знаходить свою підтримку в соціумі.

Як складний поліфункціональний інститут - сім'я завжди забезпечувала успадку- вання культури, традищій, цінностей, їх засвоєння, первинну соціалізацію індивідів, впливала на регулювання і координацію та інші види впорядкування суспільних відносин. Сучасна сім' я та сімейні цінності $є$ продуктом тривалого історичного розвитку. Цінність - це «шановані багатьма людьми матеріальні предмети, інститути і т.Д., а також відносини, що поділяються і схвалюються ними, думки, переконання, ідеї відносно соціальної значущості, бажаності і правомірності існування речей або соціальних явищ» [Николаенко 2011: 509] визначають базову основу інституту сім'ї і обумовлюються притаманними кожному конкретноісторичному типу суспільства загальними соціальними умовами: соціально-економічними, соціально-політичними, соціальнокультурними та ідеологічними, розподілом населення за демографічними, соціальнокласовими, професійними, освітніми та соціально-груповими ознаками. "Сім'я організовує формування усталених звичок, стабільну технологію соціальної поведінки, що $\epsilon$ специфічним розгортанням принципу «Контрольованої свободи» або «організованої спонтанності» [Гавриленко 2000: 25]. Отже, цінності «відіграють в людському житті вкрай важливу роль, а їх зміни так чи інакше впливають на перебіг життя i, в тому числі, на стан сім'ї» [Митрикас 2004: 65].

Складність у тому, що в ході соціалізації індивіда, а саме від того, у якій спосіб вона проходить, відбувається прийняття або відхилення цінностей, що йому пропонує сім'я та суспільство: або суспільство через сім'ю, або сім'я, в своєму намаганні змінити домінуючі в суспільстві цінності.

Втім, процес соціалізації в стратифікованому суспільстві суттевим чином визначається статусом сім'ї в системі нерівностей. Наприклад, в сім'ях буржуа «особисті якості виховані в сім'ї і найближчому суспільному оточенні (елітарна мова, естети- 
чний смак, здатність до теоретичної концептуалізації дійсності і практичної маніпуляції поведінкою інших, до розкішного споживання, престижних захоплень, амбіційних домагань та ін.) трансформуються в успішність, компетенцію, знання. Прямо протилежними є умови соціалізації трудящих. Їх сімейне виховання не готує дитину до успішного використання потенційних можливостей. Сім'я трудящих не розробляє амбіційного проекту щодо майбутнього своїх дітей і тому не готує їх до засвоєння компетенції та знань. Скоріше навпаки: сім'я прищеплює їм відчуття можливої поразки і неуспіху. Сім'я середніх класів деякі набутки стихійної соціалізації доповнює дисципліною, працездатністю, посидючістю, слухняністю, продуктивним конформізмом [Гавриленко 2000: 25-26]. Сукупність цінностей, норм, установок у сфері сімейного життя, тобто, сімейні цінності - це значимі на даний історичний час звичаї і традиції, які передаються та інтеріоризуються $з$ покоління в покоління. Вони виступають як критерії оцінювання, що дають змогу визначити нормативні, припустимі або злочинні, антисоціальні аспекти поведінки [Соціологічна енциклопедія 2008: 438], що перетворює їх в загальнообов'язкові в суспільстві в цілому або принаймні в межах окремої групи. Сiмейні цінності задовольняють соціальні потреби, головна з яких - збереження самої спільноти, за допомогою якої задовольняються усі інші соціальні потреби.

Отже, сім'я займає ключову позицію у практичному розв'язанні соціальноекономічних і духовно-моральних питань життедіяльності соціуму. Разом з тим, сім' я зазнає на собі впливу усіх суспільних диспропорцій та суперечностей, що відбиваються на ії соціальному стані. Сімейна політика за таких умов - один 3 важливіших чинників укріплення або радикальної трансформації як інституту сім'ï, так і сімейних цінностей, а сама політика похідна від домінуючої форми власності на засоби виробництва та відповідної соціально-групової структури суспільства.

Зрозуміло, що питання сім'ї, сімейних цінностей торкаються всіх без виключення людей, тому і визначаються найбільш стійким інтересом до них.

«У розвинених країнах Заходу з середини 1960-х рр., а в інших країнах Свропи 3 кінця 1980-х - початку 1990-х рр., все ясніше стали виявлятися такі ознаки трансформації сім'ї, як зменшення чисельності шлюбів, їх «старіння», збільшення числа незареєстрованих шлюбів, падіння народжуваності і iî «старіння» (народження первістків відкладається на більш пізній вік), переважання малодітних сімей, збільшення числа позашлюбних дітей i поширення добровільної бездітності.

Чи випадкове усе це? Чи воно дійсно пов'язане $з$ так званим зростанням у суспільстві тенденцій до індивідуалізму і раціоналізму?» I чи самі індивідуалізм і раціоналізм не є похідними від чогось іншого? I чому «вчені почали говорити про другий демографічний перехід (Second DemographicTransition)»? «...В середині 1980-х рр. про нього першими заговорили Дірк ван де Kaa (Dirk J. van de Каa) і Рон Лестіг (Ron Lesthaeghe), а дещо пізніше Каа стисло сформулював перелік характерних змін в стані сім'ї: перехід від «золотого століття» шлюбу до кохабітаціонного союзу; від пари «дитина-король 3 батьками» до «пари королів 3 дитиною»; від контрацепщії, з метою запобігання, до контрацепції як самовираження; від однорідного господарства до плюралістичних типів сім'ї і домашнього господарства [Митрикас 2004: 65-73], [Mitrikas 2004: 65 73].

Наприклад, зазначені ознаки трансформації інституту сім'ї знаходять 
своє відображення в інформації Свростата [Eurostat]. Так, за даними 2017 року:

- нині в Європі укладається близько 2 млн шлюбів на рік (в 2014 2,1 мЛн, а в 1964 для порівняння 3,4 млн). Якщо врахувати зростаючий рівень населення то індекс шлюбів скоротився практично вдвічі (з 7,9\% до 4,2\%);

- зростає рівень людей, хто відмовляється укласти шлюб до 30 років. В 2015 році середній вік першого шлюбу сягнув 30 років у всіх європейських країнах, за винятком двох (Литви і Польщі, де він 29 років), притому для чоловіків цей показник сягає 34-36 років;

- майже $3 / 4$ всіх сімейних пар (71,2\%) одружені. Хоча шлюб і втратив перевагу, він лишається поширеною інституцією;

- майже 1 млн. розлучень фіксується на рік (у 2015 р. укладено 2,2 млн. шлюбів і 946 тис. розлучень за останні 50 років індекс розлучень зріс у 2,5 рази). Найменший рівень розлучень в 6 , як правило, фіксується в тих державахчленах, де $\epsilon$ вищим рівень релігійності (католицької чи православної) і зберігається вплив традиційних сімейних цінностей - Хорватія, Італія, Греція, Словенія;

- відносно високий рівень неповних сімей - одиноких матерів чи батьків, що виховують дітей приблизно це 1/ 6 всіх сімей в СС;

- кількість країн 6 , що визнали одностатеві шлюби зросла до 13 (Бельгія, Данія, Німеччина, Ірландія, Іспанія, Франщія, Люксембург, Мальта, Португалія, Нідерланди, Швеція, Велика Британія...), з 2019 р. вони стануть легальними в Австрії. Греція,
Кіпр та Італія легалізували цивільні союзи між одностатевими парами. Стійко пручається тільки Східна Європа.

Наскільки можливою була б трансформація інституту сім'ї без трансформації його традиційних сімейних цінностей? Питання риторичне. А отже, трансформація самого інституту тільки і може відбутися, якщо розпочнеться процес інституціалізації нетрадиційних сімейних цінностей. Таким чином, зміни в стані сім'ї, що визначили тенденщії трансформації сім'ї та сімейних цінностей, про що йшлося вище, в Європі - 2017 виглядають наступним чином:

- збілышення середнього віку першого одруження (укладання шлюбу). За даними Європейської економічної комісії $\mathrm{OOH}$ за останні 20 років середній вік вступу у перший шлюб у Західній і Центральній Європі збільшився на 5 років - 28 років для жінок і після 30 років для чоловіків. У Східній Європі шлюбний вік зростає повільно і в середньому не перевищує 22-23 років для жінок і 25-26 для чоловіків. В Україні й Росії жінки прагнуть вийти заміж до 2324, в Естонії - середній вік 26. Вступ у шлюб після закінчення освіти, матеріального доходу, працевлаштування;

- скорочення частки шлюбних союзів

- нові форми шлюбних союзів: цивільне партнерство, однобатьківська сім'я, рекомпонована сім'я, гомосексуальна сім'я. Цивільний шлюб охоплює 8\% пар. Як наслідок, значна частка дітей народжується поза шлюбом і поза нормальним батьківством; 
- послаблення традищійних сімейних цінностей в усіх європейських країнах, попри їх різну історію чи економічне становище;

- істотні ментальні зміни: цивільне партнерство не сприймається як аморальне, нецерковний шлюб не сприймається як блуд, розлучення не сприймається як тавро, навпаки, є прийнятим способом вирішення подружніх конфліктів.

Щодо нецерковного шлюбу треба зазначити, що в світських країнах він давно не тлумачиться як блуд, бо держава взяла на себе функцію укладання шлюбу [World Values].

Так от, коли б взірцем для політики та політиків була сім'я, що складається природно-історично, то треба було б вже бити в набат, але в набат б'ють 3 іншого приводу: «Чому Східна Європа та не лише вона, пручається? I якою має стати міжнародна політика за таких умов?»

Перераховане вище досить показове у тому плані, що сімейна політика держави спроможна впливати і впливає на вектор ціннісних орієнтацій в суспільстві навіть на рівні сімейних відносин. Для соціологів тут важливе одне питання: «Що або які соціальні фактори спричиняють вибір вектору в сімейній політиці і чому саме вони?» відповідь на нього треба шукати в соціальній структурі суспільства.

Отже, за всіма тенденціями, що відбуваються в цій сфері треба шукати:

- ті моменти в державній сімейній політищі, що визначають вектор змін;

- соціальних суб' ктів, зацікавлених саме в таких змінах;

- фактори, що визначають їх зацікавленість;

- наслідки, які очікує суспільство, 3 огляду на історичну перспективу його розвитку тощо.
Звернення до такого аналізу динаміки трансформації інституту сім'ї та сімейних цінностей дозволяє отримати достовірне, об' єктивне знання.

Відзначимо, що в останні десятиліття у сімейній політиці багатьох західних держав першочергове місце займає так звана гендерна політика, що й освячує авторитетом держави зазначені зміни, які масою сприймаються з одного боку як модерні й невимушені, а з іншого - незвичні й неприйнятні.

В Україні бачимо спроби організації і проведення так званих маршів рівності, що не знаходять підтримки населення як неприйнятні, незважаючи на пропагандистську складову, якою вони супроводжуються.

Показовими щодо дотримання традиційних сімейних цінностей і інституту сім'ї $€$ результати загальноукраїнських соціологічних досліджень життєвих пріоритетів та ціннісних уподобань сучасної української молоді, зокрема сприйняття та відтворення або відхилення нею сімейних цінностей. Вони показують, що високе місце у ціннісних орієнтирах молоді займає саме традиційна сім'я та традиційні сімейні цінності. Для $74 \%$ чоловіків, і 83\% жінок шлюб є важливим і дуже важливим, однак ще важливішою є наявність дітей: для $81 \%$ чоловіків і $88 \%$ жінок. Зазначимо, що в осіб вікової групи 21-24 роки і 25-29 років прагнення бути багатим та мати успішну кар'єру поступається бажанню мати дітей [Українське покоління].

Основними пріоритетами в житті для більшості молоді є сімейне щастя (64 \%) та здоров'я (54 \%). Кар'єра (39,3\%), свобода та незалежність $(29,1 \%)$, а також багатство (28,1 \%) - посідають друге та третє місця в переліку найбільших бажаних досягнень в житті сучасної молоді [Молодь України 2017: 6-8]. 
Серед опитаних в офіційно зареєстрованому шлюбі перебуває 36,7 \% молодих осіб, не реєстрували свої відносини 8,6 \%; зі збільшенням віку респондентів збільшується частка молоді, яка перебуває у зареєстрованому шлюбі, та зменшується відсоток молодих людей, які взагалі не одружені/незаміжні. Серед міської молоді частка тих, хто живуть разом без реєстрації шлюбу, - 11,9 \%, 7,7\% - серед сільської молоді; • лише 10,6 \% опитаної молоді країни живе у незареєстрованому шлюбі, до такої форми співмешкання позитивно ставиться 28,5 \% опитаних молодих людей; водночас, майже половина опитаних молодих людей (51,1 \%) до незареєстрованих шлюбів налаштовано нейтрально [Молодь України 2017: 54-59].

Українська молодь віддає перевагу офіційному оформленню відносин, а шлюби після 30 років, особливо для жінок, сприймають як аномалію. Найоптимальнішим віком для одруження і народження дітей вважають 25 років. Абсолютна більшість (86\%) бачить своє майбутнє «у шлюбі 3 дітьми».

У цивільному шлюбі живуть не більше 7\% молоді, при цьому відверто віддають перевагу такому шлюбу над офіційним тільки $2 \%$ опитаних. Хоча значна кількість молодих людей позитивно ставиться до цивільних шлюбів (спільне проживання без реєстрації відносин), дाя більшості це $є$ своєрідним випробувальним етапом перед офіційним укладенням шлюбу, аніж ціллю

Найважливішими у виборі чоловіка/дружини, на думку молоді, є спільність інтересів (84\%) та особистість (79\%). Такий підхід загалом підтримують представники всіх вікових груп, як чоловіки, так і жінки.

Українська молодь майже одностайна в тому, як вона бачить своє сімейне майбутнє - 86\% респондентів обрали опцію «у шлюбі з дітьми». При цьому важливі обидва компоненти: і офіційний шлюб, і діти.
Опції «у шлюбі, але без дітей», «у цивільному шлюбі з/без дітей» мають мізерну підтримку в 3\%. На тлі решти України виділяється Київ, адже тут 6\% готові до шлюбу без дітей. У столиці зафіксовано найвищий відсоток тих, кому було важко відповісти на це питання -однозначні щодо свого сімейного майбутнього (90\% проти $82 \%$ у чоловіків). $14 \%$ (на решті території цей показник не перевищував 6\%). Найбільше значення сучасна українська молодь надає таким нематеріальним цінностям, як бути вірним партнеру/партнерці та друзям, а також зберігати незалежність. Для майже 90\% опитаних ці речі $є$ важливими та дуже важливими [Українське покоління].

Порівняння результатів досліджень свідчить, що трансформація інституту сім'ї в українському суспільстві поступово починає відбивати загальноєвропейські тенденції. Але якщо для України це можна розглядати як тенденції, то для європейських країн, враховуючи часову тривалість - як вже закономірний процес, під час якого відбулися навіть істотні ментальні зміни (останні в суспільній думці населення України ще визначаються своєю латентністю: так, тільки 59,3 \% молоді негативно ставиться до одностатевих шлюбів [Молодь України 2017: 68-69].

Однак процес трансформації сімейних цінностей лише здається закономірним. За ним стоїть не природно-історичний закон, а відповідна законодавча ініціатива, що призводить до чітко розрахованого процесу реінституціоналізації сімейних відносин. Тут треба було б проаналізувати зміни в сімейному законодавстві Свропейських країн, де вже легалізована сімейна політика, що спрямована на інституціалізацію нетрадиційних цінностей і відзначити ще один суттєвий момент: в час, коли західні і тоді ще радянські країни мали протилежні політико-еко- 
номічні системи, але їх інститути сім'ї та сімейні цінності переважно грунтувалися на природно-історичних законах, а отже, в суспільствах цих країн, явища, що характеризуються в наведених вище тенденціях, визнавалися девіантними, або нетрадиційними і неприйнятними до визнання їх в якості сімейних цінностей.

У 1970 році в світ вийшла книга американського соціолога і футуролога Елвіна Тоффлера «Шок майбутнього» (Future shock,1970 р.) [Тофлер 2002: 557], що одразу стала бестселером. У передмові до книги автор написав: «Ця книга про те, що відбувається 3 людьми, коли на них обрушуються зміни. Вона про те, як ми адаптуємося - або не адаптуємося - до майбутнього» [Тофлер 2002: 15]. Розмірковуючи над майбутнім сім'ї, він зазначає, що сім'я може і не зникнути, і не увійти в новий золотий вік. Найімовірніше, що вона розіб' ється вщент, але лише для того, щоб потім прийняти новий і дивний вигляд. [Тофлер 2002: 264], а тому розділ так і називається «Зламана сім'я».

До такого роду «нового і дивного вигляду» в надіндустріальному суспільстві члени «поступово примушуються до експериментів з новими формами сім'ї, а то й поза сімейного способу життя. Можливо, підприємливі малі групи будуть випробувати якісь екзотичні сімейні відносини, а дітонародження буде відірване від його біологічної основи» [Тофлер 2002: 265]. Автор пише, що найбілыш екзотичним тут може стати професійне батьківство, що чудово узгоджується 3 нездоланним рухом суспільства до спеціалізації. Робітник як психо-генотип, прибиральниця як психогенотип тощо. Соціальна структура як структура соціальних нерівностей має зберігатися, а при змінах у професійній структурі виробництва можна буде виробляти і відповідні психо-генотипи. На зміну су- часній соціалізації прийде генетика, психологія та медицина [Тофлер 2002: 264]. Але Тофлер, фіксуючи факт змін у сімейних відносинах, не викриває їх причини, він лише фіксує і описує зміни. Нам же здається, що сім'я почала розглядатися як те, що приносить значні збитки в капіталістичній економічній діяльності. Одружена людина має підтримувати сім'ю, а неодружена - лише саму себе. Коли дозволити їй перебувати у позашлюбних, а то й безшлюбних відносинах, у невпорядкованих статевих відносинах, включаючи одностатеві, інститут сім'ї втрачає сенс, а економічні витрати на ї̈ підтримку зменшуються. Соціальна енергія індивідів починає витрачатися не на розв'язання соціальних проблем, що виникають на стику міжгрупових відносин, а на пошук статевого партнера та захист права на вільний пошук. Тут починає діяти фрейдівська сублімація як захисний механізм: зняття внутрішньої енергії, що породжується в опорі до соціальної несправедливості існуючого соціального устрою, але перенаправляється на досягнення права свободи у виборі статевого партнера та статевих практик.Можна сказати так, що сублімація тут перетворюється в сублімацію статевого до складного сексуально-право-політичного.

Однак, не лише материнство, а й саме поняття батьківського статусу поступово досить радикально переглядається, тим більше, що набирає обертів ще одна тенденція, - ствердження ідеї про те, що функція народження дитини позбавляє жінку права на гендерну рівність, але на рівність не з чоловіком, бо й чоловік - тепер лише один 3 гендерів, яких вже нараховується майже шістдесят: андрогін, бігендер, інтерсексуал, гендерквір транссексуал тощо. I всі вони рівні як саме гендери. Коли так, то проблема соціальної рівності ніби-то йде в 
небуття, а разом 3 нею йде в небуття і проблема соціальної справедливості.

Виходить так, що постановка питання соціальної рівності неправомірна, бо утопічна, а постановка питання про гендерну рівність - нагальна потреба дня. Насправді ж питання про гендерну рівність не $є$ питанням про соціальну рівність між жінками та чоловіками, та про вікове пригноблення жінок. Таке питання поставлене давно і багато в чому вже було роз' язане. Це питання про право вибору (соціальної) статі, тобто про вище зазначені гендери i, наприклад, про роль так званого фемінізму у впровадженні гендерної політики. Фемінізм постав на жіночому питанні, але давно вийшов за його межі у велику політику зміни людського генотипу.

«У міру того як гомосексуалізм стає соціально більш прийнятним» [Тофлер 2002: 273], він створює неабиякі можливості для маніпуляцій статевими стосунками та надання їм політико-правового забарвлення.

Швидкість, $з$ якою гомосексуальні відносини нині стають в індустріальних країнах респектабельними, ясно вказує, що процес розгортається, що він контрольований і що в його розгортанні не остання роль належить науці.

«Бездітні шлюби, професійне батьківство, пенсіонери, які виховують дітей, корпоративні сім'ї, комуни, гомосексуальні сімейні союзи, полігамія - все це, однак, мала частина сімейних форм і відносин» [Тофлер 2002: 273], які науковці відносять до категорії новаторських дій меншин, тобто до категорії експериментування. Не без стихійного експериментування, але експериментування над статевими відносинами процес не стихійний, а керований, і від волі більшості тут мало що залежить, бо ії інтерпретують не інакше як статистичну більшість, а не як носія соціальної волі.
Враховуючи, що Тофлер посилається на вже започаткові на час написання книги нововведення в сімейні практики американського і європейських суспільств, висновком може слугувати думка про те, що «правильним» слід вважати сімейну політику, орієнтовану «на зміну всього ладу сучасної цивілізації, по суті антисімейною, ворожою сім'ї, несприйнятливою до ії проблем і хвороб» [Антонов 1996: 246].

Українські соціологи ретельно відслідковують вище описані зміни, правда, переважно не наголошуючи на їх штучному характері. Вони фактично фіксують, що нас ще не торкнулося західне повітря в сімейній політищі і тому у нас спостерігаються дещо інші результати.

Проте, формування емансипативної системи цінностей [Ціннісна складова 2014: 122] в сучасному суспільстві, зокрема в українському, що відбувається під впливом ряду факторів глобалізаційного, державно-політичного, соціокультурного характеру спрямоване на трансформацію інституту сімї та сімейних цінностей, в якому Україна допоки обирає поступовість та розважливість. Вона віддає перевагу соціально-культурній значущості сім'ї і допоки не надає економічній стороні справи переважного значення.

Коли говорять, що в «Україні існують дві системи цінностей, які умовно можна назвати «радянсько-ностальгійною» та «демократично-неотрадиціоналістською», що жодна 3 них не є легітимною на соцієтальному рівні і наразі не може виступати основою суспільного консенсусу» [Модернаційні процеси 2014: 124], то слід відзначити, що протиставлення двох систем цінностей, може означати тільки латентну вимогу поглиблення вище зазначеної гендерної політики, трансформування української сім'ї та національних сімейних цінностей у відповідності до західних стандартів.

Соціологи зазначають, що соціальний час $є$ продуктом наших власних соціально 
орієнтованих дій, включаючи і політикоправові, що можуть бути спрямовані або на збереження традиційної сім'ї як нашого культурно-історичного надбання або відмовитися від традищії і національної культури.

Як висновок можна зазначити, шо:

- трансформація інституту сім'ї та сімейних цінностей насправді є процесом їх реінституціоналізації, перетворення в нетрадиційні і керовані ззовні;

- сімейна політика в світі набула вигляду двох взаємовиключних векторів: перший реалізується в західних країнах і спрямований фактично на деінстиціоналізацію сім' $і 1$, а другий - на державну підтримку традиційної сім'ї та природно-історичні ії зміни;

- так звана гендерна політика фактично вийшла за межі політичної, економічної та соціально-культурної проблематики; вона не задовольняється штучним створенням рухів на iï підтримку та пропаганди і почала впроваджуватися за допомогою освіти і науки: медицини, педагогіки, психології, соціології, а найголовніше, поступово переходить на рівень генетики, що вимущує задуматися над іï практичними наслідками для людства взагалі.

3 огляду на сказане, треба ще раз звернути увагу на слова Тоффлера, що люди «примушуються до експериментів 3 новими формами сім'ї», як і трансформації статі, до речі, будучи абсолютно впевненими, що діють у згоді з власною волею.

\section{Список літератури}

1. Антонов, А. И. \& Медков, В. М. (1996: 304). Социология семьи. Москва: Издательский дом международного университета в Москве.

2. World Values Survey - 2017. [Електронний ресурс]. - Режим доступу: http://www.worldvaluessurvey.org/wvs.jsp

3. Eurostat [Електронний pecypc]. https://ec.europa.eu/eurostat/web/income-and-living-conditions/overview

4. Гавриленко, I. М. (2000: 464). Соціологія. Кн. 2. Соціальна динаміка : навчальний посібник. К. : ВЦ «Київський університет».

5. Митрикас, А. А. (2004: 65 - 73, № 5). Семья как ценность: состояние и перспективы ценностного выбора в странах Европы [Електронний ресурс]. - Режим доступу: http://ecsocman.hse.ru/data/382/176/1217/0 08.MITRIKAS.pdf

6. Модерні процеси та трансформація цінностей (Матеріали засідання круглого столу «Ціннісні аспекти модернізаційних процесів сучасного соціуму») [Електронний ресурс]. Режим доступу:

https://www.hse.ru/data/2013/12/16/133841 2111/\%D0\%A1\%D0\%BE\%D1\%86\%

7. Молодь України - 2017. Результати соціологічного дослідження (2017: 72). Тернопіль : ТОВ «Терно-граф».

8. Николаенко В, Л. (2011: 577). Социология культуры: краткий словарь. / [науч.ред. Туленков Н. В.].- К. : ИПК ГСЗУ.

9. Сімейний кодекс України (Відомості Верховної Ради України (ВВР), 2002, N 2122, ст.135) ( Із змінами, внесеними згідно із Законом N 407-IV ( 407-15 ) від 26.12.2002, ВВР, 2003, N 7, ст.70 ) [Електронний ресурс]. - Режим доступу: http:/ / zakon.rada.gov.ua/laws/show/294714/ed20030101

10. Сорокин, П, А. Социальная стратификация и мобильность (1992: 302 - 373).

11. Соціологічна енциклопедія (2008: 456). [укл. Городяненко, В. Г.]. К. : «Академвидав».

12. Соціологія : підручник (2010: 224) [ред. Требін М. П.]. Х. : Право.

13. Стан сингулярності: соціальні структури, ситуації, повсякденні практики (2017: 180) [ред. Макеєв, С., Оксамитна, С.]. К. : НаУКМА.

14. Тоффлер Э. Шок будущего (2002: 557). М. : ООО «Издательство АСТ», [Електронний ресурс]. - Режим доступу: 
http://yanko.lib.ru/books/cultur/tofflerfuture_shock-ru-1.pdf

15. Українське покоління Z. Цінності та орієнтири. Результати загальнонаціонального опитування [Електронний ресурс]. - Режим доступу:

https://zaxid.net/resources/newsfiles/319940 _Ukr_Generation_ukr_inet-1.pdf

16. Ціннісна складова модернізаційних процесів у сучасному соціумі України : кол. Монографія (2014: 340) [ред. Балакірєва, О.М.] ; НАН України, ДУ «Інститут економіки та прогнозування НАН України». ISBN 978-96602-7425-9

\section{References}

1. Antonov, A.I. \& Medkov, V.M. (1996: 304). Family Sociology. Moscow: Publishing House of the International University in Moscow.

2. World Values Survey - 2017. http://www.worldvaluessurvey.org/wvs.jsp

3. Gavrilenko, I. M.. (2000: 464) Sociology. Book 2. Social dynamics: textbook. K .: Kiev University Center.

4. Eurostat https://ec.europa.eu/eurostat/web/income-and-living-conditions/overview

5. Mitrikas, A. A. (2004: 65 -73) Family as value: state and prospects of value choice in European countries Retrieved from

6. http://ecsocman.hse.ru/data/382/176/1217/0 08.MITRIKAS.pdf

7. Modern processes of transformation of values (Materials for the round table «Cognitive aspects and modern processes of the social society») [Electronic resource]. - Access mode: https://www.hse.ru/data/2013/12/16/133841 2111/\%D0\%A1\%D0\%BE\%D1\%86\%.pdf

8. Valuable aspects of modernization processes of modern society Retrieved from https://www.hse.ru/data/2013/12/16/ $1338412111 / \%$ D0\%A1\%D0\%BE\%D1\%86\%.pdf

9. Youth of Ukraine - 2017. Results of sociological research (2017: 72). Ternopil: Ltd Terno-graf.

10. Nikolaenko, V. L. (2011: 577). Sociology of culture: a brief dictionary / [ed. Tulenkov, N.V.]. K.: IPK GSZU.

11. Family Code of Ukraine (Bulletin of the Verkhovna Rada of Ukraine (VVR) (2002: 21-
22).

http://zakon.rada.gov.ua/laws/show/294714/ed20030101.

12. Sorokin, P. A. Social stratification and mobility (1992) Moskva.: Politizdat Publ, pp. 302 - 373.

13. Sociological Encyclopedia (2008: 456) Gorodyanenko, V.G. (Ed.). K. : Academic Edition.

14. Sociology: a textbook (2010: 224). Trebin , M. P. (Ed.). Kharkov : Pravo Publ.

15. The state of singularity: social structures, situations, everyday practices (2017: 180) Makeyv (Ed.). Kiev.: NaUKMA

16. Toffler E. Future shock (2002: 557) Moskva: ACT Publ 557 p. Retrieved from http://yanko.lib.ru/books/cultur/tofflerfuture_shock-ru-l.pdf

17. Ukrainian generation Z. Values and landmarks Retrieved from

https:// zaxid.net/resources/newsfiles/319940 _Ukr_Generation_ukr_inet-1.pdf

18. Valuable component of modernization processes in modern society of Ukraine: count. monogr (2014: 340). Balakireva, O.M (Ed.). Kiev: National Academy of Sciences of Ukraine, Institute of Economics. and predicting. 